\title{
The Role of Green Fluorescent Protein (GFP) in Transgenic Plants to Reduce Gene Silencing Phenomena
}

\author{
Hany A. El-Shemy ${ }^{1,3 *}$, Mutasim M. Khalafalla ${ }^{2,3}$, \\ and Masao Ishimoto ${ }^{3}$ \\ ${ }^{1}$ Faculty of Agriculture Research Park (FARP) and \\ Biochemistry Department, Faculty of Agriculture, Cairo \\ University, Giza 12613, Egypt \\ ${ }^{2}$ Commission for Biotechnology and Genetic Engineering, \\ National Centre for Research P.O. Box 2404 Khartoum, \\ Sudan \\ ${ }^{3}$ National Agricultural Research Center for Western \\ Region, 6-12-1 Nishifukatsu, Fukuyama, Hiroshima 721- \\ 8514, Japan
}

Received 9 August 2008

Revised 18 October 2008

Accepted 24 October 2008

\begin{abstract}
The green fluorescent protein (GFP) of jellyfish (Aequorea victoria) has significant advantages over other reporter genes, because expression can be detected in living cells without any substrates. Recently, epigenetic phenomena are important to consider in plant biotechnology experiments for elucidate unknown mechanism. Therefore, soybean immature cotyledons were generated embryogenesis cells and engineered with two different gene constructs ( $\mathrm{pHV}$ and $\mathrm{pHVS}$ ) using gene gun method. Both constructs contain a gene conferring resistance to hygromycin (hpt) as a selective marker and a modified glycinin (11S globulin) gene (V31) as a target. However, sGFP(S65T) as a reporter gene was used only in pHVS as a reporter gene for study the relation between using sGFP(S65T) and gene silencing phenomena. Fluorescence microscopic was used for screening after the selection of hygromycin, identified clearly the expression of $s G F P(S 65 T)$ in the transformed soybean embryos bombarded with the pHVS construct. Protein analysis was used to detect gene expression overall seeds using SDS-PAGE. Percentage of gene down regulation was highly in $\mathrm{pHV}$ construct compared with pHVS. Thus, sGFP(S65T) as a reporter gene in vector system may be play useful role for transgenic evaluation and avoid gene silencing in plants for the benefit of plant transformation system.
\end{abstract}

Key words: epigenetics, green fluorescence protein, gene gun, transgenic soybean.

*For correspondence: helshemy@hotmail.com

\section{Introduction}

The advent of the technology to transform plants with DNA sequences such as the generation of transgenic plants, allowed an entirely new direction for the exploration of genetics.

GFP has grown in popularity as a reporter gene in molecular biology research. In plant transformation systems with the problem of low efficiency, the nondestructive analysis of putative transformed cells and tissues using a reporter gene such as the GFP (jellyfish green fluorescence protein) gene could significantly help to optimize transformation protocols and generate transgenic plants (Stewart, 2001; El-Shemy et al., 2004, 2006, 2007).

With the successful development of procedures for transformation, transgenic plants and their progeny have been studied for continued stable expression of the foreign gene through several generations. These studies have revealed that in some cases the transgene expression was lost in a variable proportion of the progeny. This phenomenon, called "gene silencing", has been studied most extensively in dicot plants, such as tobacco, petunia, tomato, and buckweed (Matzke and Matzke, 1995; Meyer, 1995). Several mechanisms have been proposed to explain the phenomena of gene silencing (Matzke et al., 2001; Meyer, 1995; Stam et al., 1997). Two types of silencing occur in plants and in other eukaryotes: transcriptional gene silencing (TGS) and posttranscriptional gene silencing (PTGS) (Carthew,2001; Waterhouse et al., 2001a,b). Silencing at the transcriptional level is thought to occur primarily by methylation of promoter sequences, thereby interfering with assembly of the transcription factors and/or by attracting chromatin re-modeling proteins to these sites (Meyer, 2000; Wang and Waterhouse, 2002).

Gene silencing and its implications for transgene expression is an area of intense research at this time, and the reader is directed to recent reviews on this large subject (Meyer, 2000; Vance and Vaucheret, 2001; Wang and Waterhouse, 2002). For that, the aim of this study is to identify the role of $s G F P(S 65 T)$ to reduce or avoid the gene silencing phenomenon in transgenic plants.

\section{Results}

Embryogenic cells induced from a soybean cultivar, Jack, were transformed by microparticle bombardment with the pHVS, which contains a modified globulin gene, a selectable marker gene hpt and a reporter gene $s G F P(S 65 T)$. To optimize the conditions for particle delivery into the embryogenic tissues, transient expression of the sGFP(S65T) gene was detected one day after bombardment with a fluorescent microscope. According to the intensity and number of foci expressing 
A: Embryos
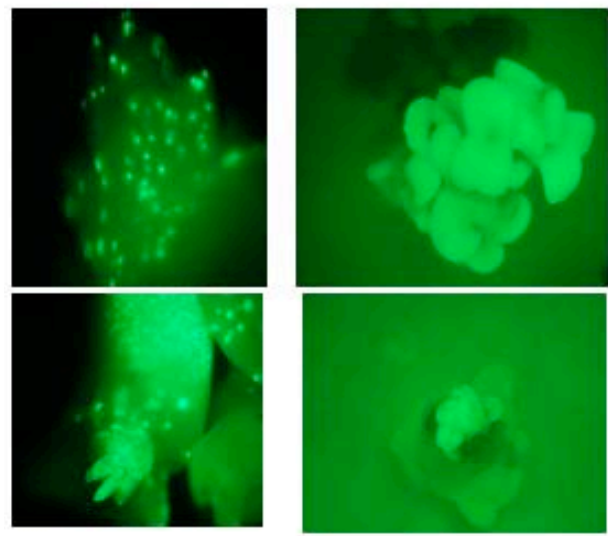

\section{B: Leaves}
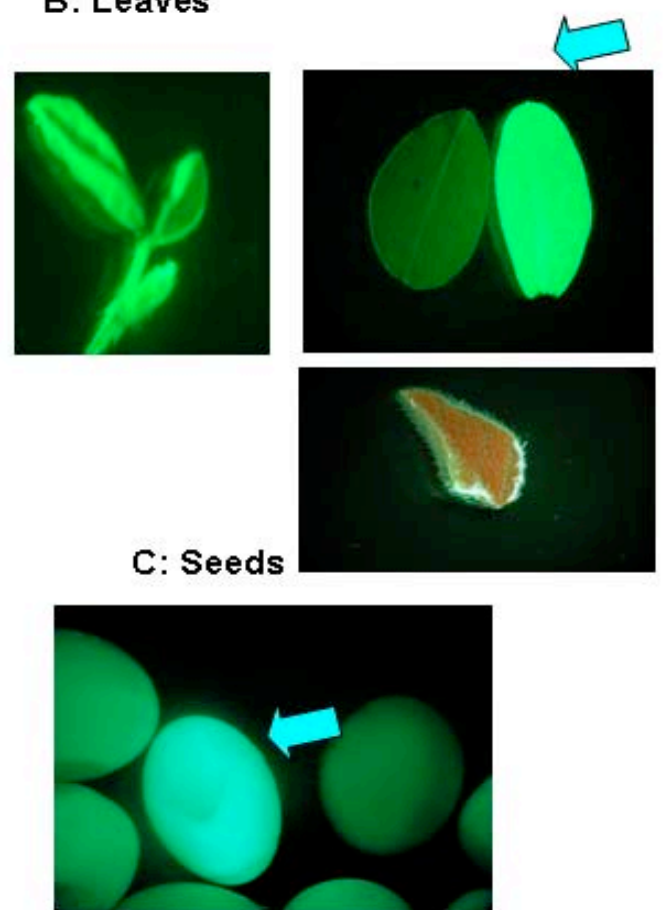

Fig. 1. Visualization of $s G F P(S 65 T)$ expression in transformed soybean plantlets. Embryos (A), leaves (B) and seeds (C).

GFP, we decided on a pressure of 1350 psi and distance of $6 \mathrm{~cm}$ for the delivery. Expression of $s G F P(S 65 T)$ in soybean was also monitored during the selection with hygromycin and development of plants (Fig. 1).

In this experiment, the conditions for delivery of particles coated with plasmids according to the transient expression was successfully optimized of the sGFP(S65T) gene (Fig. 2).

Transformation was achieved by coating each plasmid, either pHV or pHVS, onto the particles and bombarding embryogenic tissues. Hygromycin-resistant cells were selected then matured in FNLOS3S3 liquid medium and germinated on MSO media. All regenerated plants obtained from the two constructs were confirmed the presence of $h p t$ gene by PCR analysis. Out of a total of 122 regenerated plants obtained from the introduction of pHVS, 82 plants produced an expected band with a 0.5 $\mathrm{kbp}$ of PCR product within the hpt gene (Table 1). On the

Table 1 Gene silencing efficiency in soybean by using two vector systems.

\begin{tabular}{llc}
\hline Construct & pHVS & pHV \\
\hline Regenerated plants & 122 & 98 \\
hpt-positive by PCR & 82 & 29 \\
Transgenic plants $^{\mathrm{a}}$ & $49\left(29^{\mathrm{b}} / 20^{\mathrm{c}}\right)$ & 21 \\
Absence of glycinin & $24\left(10^{\mathrm{b}} / 14^{\mathrm{c}}\right)$ & 15 \\
Gene Silencing \% & $58.5\left(34.4^{\mathrm{b}} / 70^{\mathrm{c}}\right)$ & 71.4 \\
\hline
\end{tabular}

aTransformats giving $h p t$ and sGFP bands by PCR analysis

${ }^{\mathrm{b}}$ Transgenic soybean expressing sGFP

'Transgenic soybean not expressing sGFP other hand, 29 of 98 regenerated plants obtained from the introduction of $\mathrm{pHV}$ yielded the $0.5 \mathrm{kbp}$ hpt fragment in PCR analysis (Table 1). PCR analysis for sGFP(S65T) genes was conducted in the soybean plants that yielded a hpt band to confirm the presence of all transgene cassettes (Fig. 2). The expression of SGFP(S65T) was detected in about $52 \%$ of the hpt-positive soybeans engineered using pHVS (Fig. 2). Southern blot analysis was performed to confirm the integration, and to estimate the copy numbers of transgenes. Total genomic DNA, which was isolated from transgenic plants to as certain the presence of all transgene cassettes by PCR (Fig. 2 ), was digested with Sacl, and hybridized with one of the two probes for hpt and sGFP(S65T) (Fig. 3). All the transformants analyzed here yielded one to seven bands hybridized with the hpt probe in addition to a common band at around $6.6 \mathrm{kbp}$ (Fig. 3A). On the other hand, DNA isolated from untransformed plants hybridized with the sGFP(S65T) probe, even though GFP is not derived from plants. This maybe caused by unspecific hybridization of the probe with soybean genomic DNA (Fig. 3B). The individual plants exhibited different banding patterns, confirming that they resulted from different events.

The accumulation of glycinin was confirmed by SDSPAGE and Tricine SDS-PAGE analysis of the globulin fraction extracted from transgenic seeds (Fig. 4). The modified glycinin V3-1 could not be distinguished from endogenous glycinin subunits by the SDS-PAGE, because the modified glycinin contains only six additional amino acids in the basic subunit. The results of protein analysis were confirmed by immunoblotting (Fig. 5). 


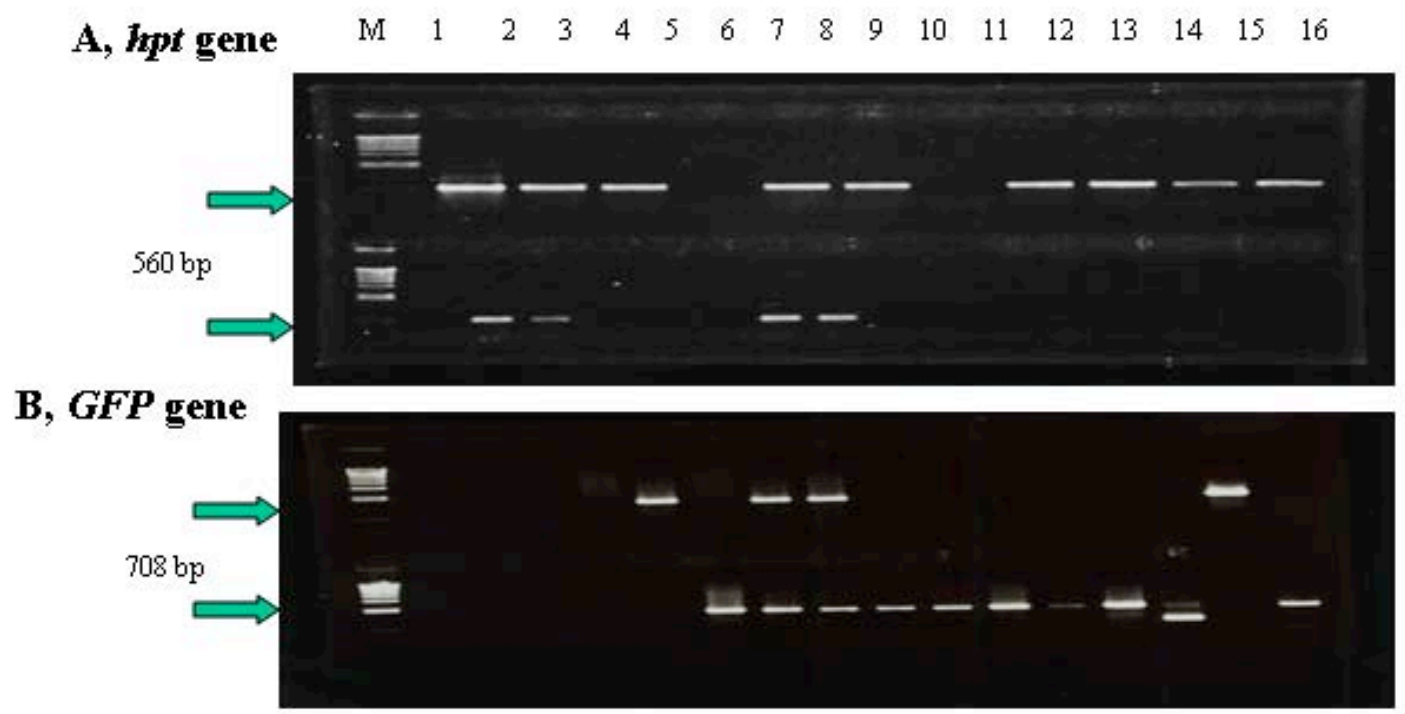

Fig. 2. Detection of foreign genes in transgenic soybean plants by PCR: $h p t(\mathbf{A})$, and sgfp (B) genes. lane 1 (untransformed control), 2-15 (transformed soybeans with pHVS and pHV), and 16 (plasmid with pHVS). Arrowheads: expected $560 \mathrm{bp}$ and $708 \mathrm{bp}$ fragments of hpt and sgfp genes.

\section{Discussion}

The potential of GFP appears to be greater than its current applications as researchers seeking to characterize GFP under novel conditions reveal new uses for the protein (Stewart, 2001; Richards et al., 2003; El-Shemy et al., 2004, 2006). This increased potential is especially pertinent to plants, since it is often desirable to quantify gene expression on the plant and in the field.

GFP can partially replace antibiotic selection and be of great use when the organogenesis or conversion of transformation procedures is inefficient under antibiotic or herbicide selection (Stewart, 2001). It could be helpful in isolating events during the early stages of transformation experiments as described here (Fig. 1). An example of this was the transformation of sugarcane with sGFP(S65T) (Elliot et al., 1999).

Silencing was first observed concerning transgene expression in plants about 10 years ago, with a report that transformation of petunia with extra copies of the chalcone synthase gene could result in a block in expression of both the transgene and the corresponding endogenous gene (Napoli et al., 1990; Lessard et al,, 2002). This phenomenon was termed cosuppression (Napoli et al., 1990). Suppression of endogenous glycinin

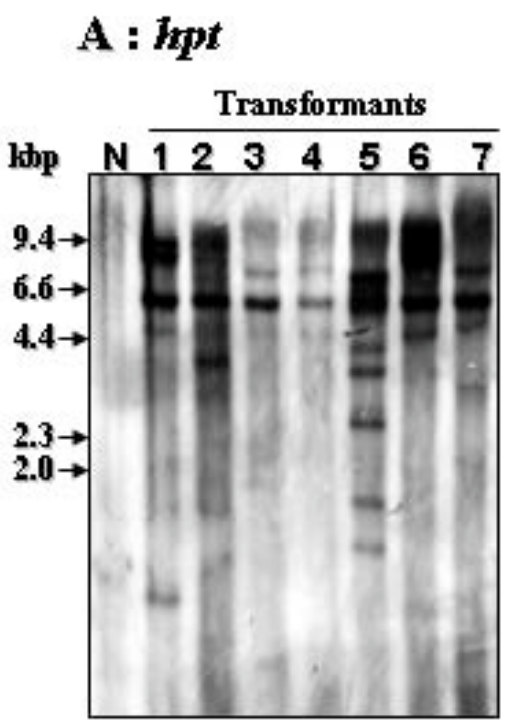

\section{B : $\operatorname{sGFP(S65T)}$}

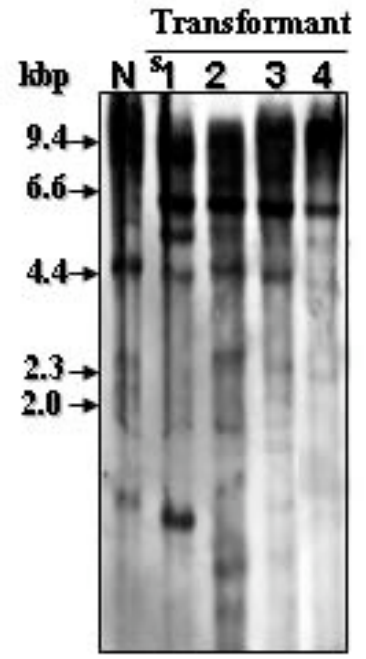

Fig. 3. Southern blot analysis of soybeans transformed with pHVS and pHV. Total DNA was digested with Sacl and loaded in lane N (untransformed control), 1-4 (transformed soybeans with pHVS), and 5-7 (transformed soybeans with pHV). Separated DNA was transferred to a nylon membrane and hybridized with each probe containing the coding region of $h p t(\mathbf{A})$, and $s G F P(S 65 T)(\mathbf{B})$. 


\section{A}

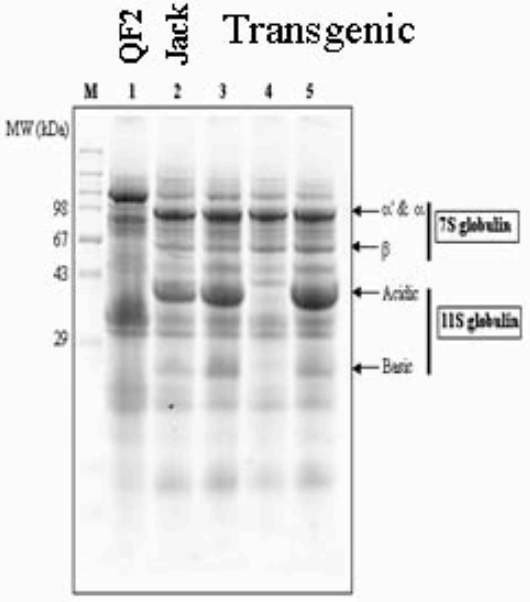

B

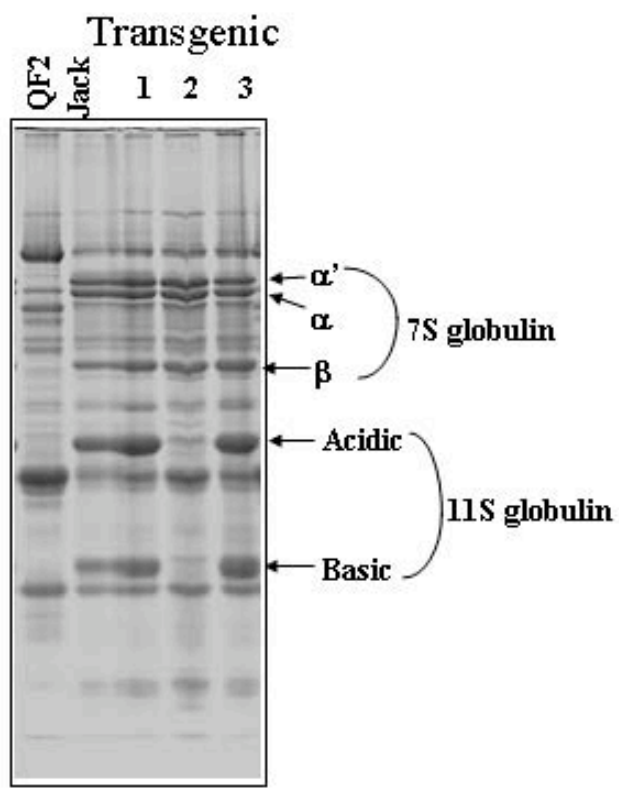

Fig. 4. Tricine-SDS-PAGE (A) and SDS-PAGE (B) analysis of components of seed storage proteins in transformed soybean. Globulin fractions were isolated from QF2 (mutant line lacking $7 S$ and $11 S$ globulin), Jack (untransformed control) and transformants, $25 \mu \mathrm{g}$ of each fraction was fractionated by SDS-PAGE and then stained with CBB.

in the transformed soybean was frequently observed on the introduction of the modified glycinin V3-1 gene (Table $1)$.

The effects of transgenic copy number on the level of gene expression are known to be complex. Though it was anticipated that the increase of transgene copy number would increase the expression level (Dai et al., 2001; El-Shemy et al., 2004, 2006, 2007), it is now known that gene co-suppression phenomena frequently occur in transgenic plants with repeated transgenes or an unusual structure such as inverted repeats (Vaucheret et al., 1998). Such events are likely to be powerful inducers of co-suppression and methylation (Luff et al., 1999).

The glycinin subunit polypeptides in some transformants were intensely stained with $\mathrm{CBB}$ compared to non-transformants (Fig. 4). This may be due to the accumulation of the modified glycinin V3-1 in transgenic seeds. On the other hand, some transgenic soybeans lack all subunits of glycinin, suggesting the transgene may cause the suppression of endogenous glycinin genes by the effect of gene silencing (Table 1, Fig. 4 and Fig. 5). The ratio of gene silencing was lower in transformants engineered with the pHVS construct and selected based on GFP expression than transgenic soybean engineered with the pHV construct (Table 1).

It is suggested that the transgene causes the effects of gene silencing. There is some predictability to silencing. Counterintuitively, an increased copy number of a transgene can correlate with an increased risk of silencing (Lessard et al., 2002). However, determining whether silencing will occur in particular transgenic plants is still largely an empirical problem, requiring testing of transgene expression in the individual plants. Two general approaches can be used to avoid problems with silencing (Lessard et al., 2002). First, the use of gene delivery methods, such as Agrobacterium-mediated transformation, that result in integration of relatively few copies of a transgene into the genome,can minimize problems with silencing (Dai et al., 2001). Second,the use of constructs in which matrix attachment regions

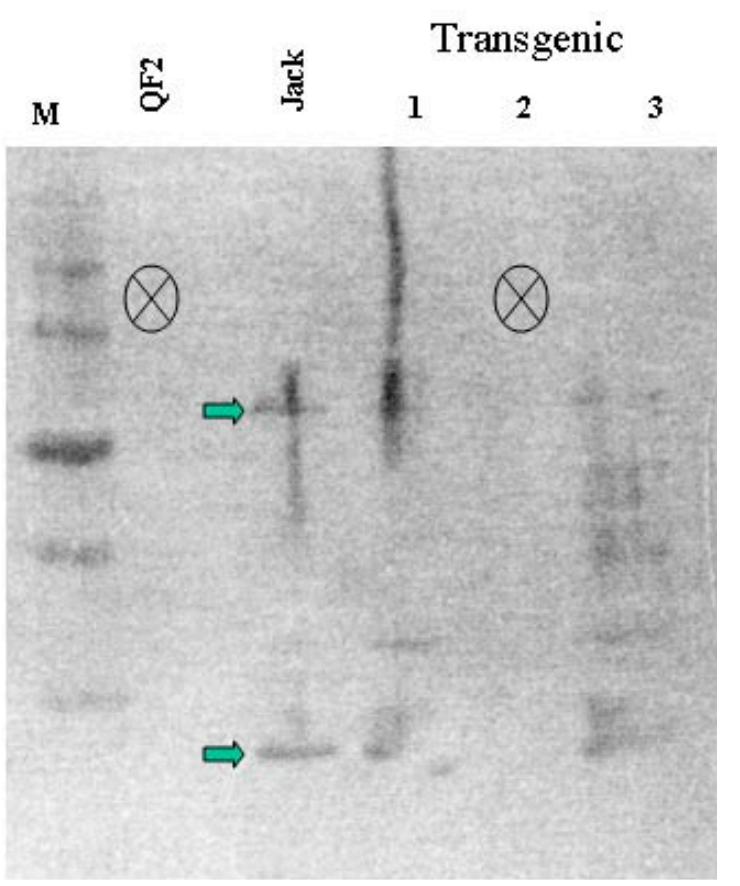

Fig. 5. Detection of storage proteins (11S globulin) in soybean transgenic seed proteins (Immune-blotting). QF2 (mutant line lacking 7S and 11S globulin), Jack (untransformed control) and transformants. lane 1 (transformed soybeans with pHVS), lane 2(transformed soybeans with $\mathrm{pHV}$ ) and lane 3 (transformed soybeans with pHVS).

Arrowheads expected fragments of $11 \mathrm{~S}$ globulin (Jack, untransformed control, lane 1, 3 transformed soybeans with pHVS).

QF2 and Lane 2 transformed soybeans with pHV showed silencing of internal $11 \mathrm{~S}$ globulin. 
flank the transgene may also minimize silencing (Spiker and Thompson,1996). The results expected that the transgenic soybeans accumulating the modified glycinin V3-1 to have a higher level of methionine than nontransformants (Fig. 4). Up to date, gene silencing was seen as a problem for plant genetic transformation, as it prevented reliable expression of a desired phenotype within transgenic plants (Taylor and Fauquet, 2002). However, with increasing knowledge of the mechanisms underlying this phenomena, and realization that it can be utilized to down-regulate native genes within the plants, and it will become a powerful tool in future transgenic applications (Vance and Vaucheret, 2001; Lessard et al,, 2002).

The silencing effect appeared stochastic in nature, with patterns and variegation appearing in the tissues of the transformed plants, much like previous observations of somaclonal variation and paramutation (GrantDownton and Dickinson, 2005). This 'co-suppression' of an endogenous gene by extra copies of the same gene was also accompanied by observations that insertion of entirely foreign coding gene sequences did not necessarily lead to their expression (Grant-Downton and Dickinson, 2005). Other experimentation with transgenic technology led to the discovery that this gene silencing effect on endogenous genes by inserted DNA was more consistent when the inserted gene copy was in reverse or 'antisense' orientation (Van der Kroll et al., 1988). Perhaps more remarkable was the realization that a whole copy of the gene was not even required to elicit this effect (Grant-Downton and Dickinson, 2005). Clearly, adding new fragments of DNA to the genome not only resulted in the silencing of their own expression, but also the specific silencing of endogenous genomic sequences to which they were homologous (Grant-Downton and Dickinson, 2005). An intact copy with no nucleotide mutation was being 'silenced' by the presence of a foreign sequence at another site in the same genome (Grant-Downton and Dickinson, 2005).

Biomolecular techniques allow for the insertion of the gene for GFP right before the stop codon (Chalfie et al., 1994). The cell would keep making hemoglobin, but before reaching the stop codon it would make the GFP (Chalfie et al., 2004; Fig. 6).

There were three reasons Prasher thought that GFP could potentially become a significant tracer molecule. Firstly, if enough protein with attached GFP were made, it should be easy to detect and to trace it as it moved through the cell, because irradiating the cell with ultra violet light would cause the GFP attached to the protein to fluoresce. Secondly, Shimomura had shown in 1974 that GFP was a fairly small protein. This was important because a small protein attached to the protein of interest was less likely to hinder its proper function. Its small size would also allow it to follow the fused protein, especially in organelles like neurons, whereas the diffusion of large proteins would be difficult. Thirdly, it had been shown that once GFP was made in the jellyfish, it was fluorescent. Most other bioluminescent molecules require the addition of other substances before they glow. For example, aequorin will glow only if calcium ions and coelenterazine have been added, and firefly luciferase requires ATP, magnesium, and luciferin before it luminesces. This would make GFP a much more versatile tracer than either aequorin or firefly luciferase, which were being used as tracers. Besides attaching GFP to a protein and making it a fluorescent tag, Prasher also thought that GFP could potentially be a very useful reporter molecule. For activating protein production, DNA promoters are used; these are sequences of DNA next to genes that contain the information about where and when the gene should be read and make the protein. If GFP is linked to

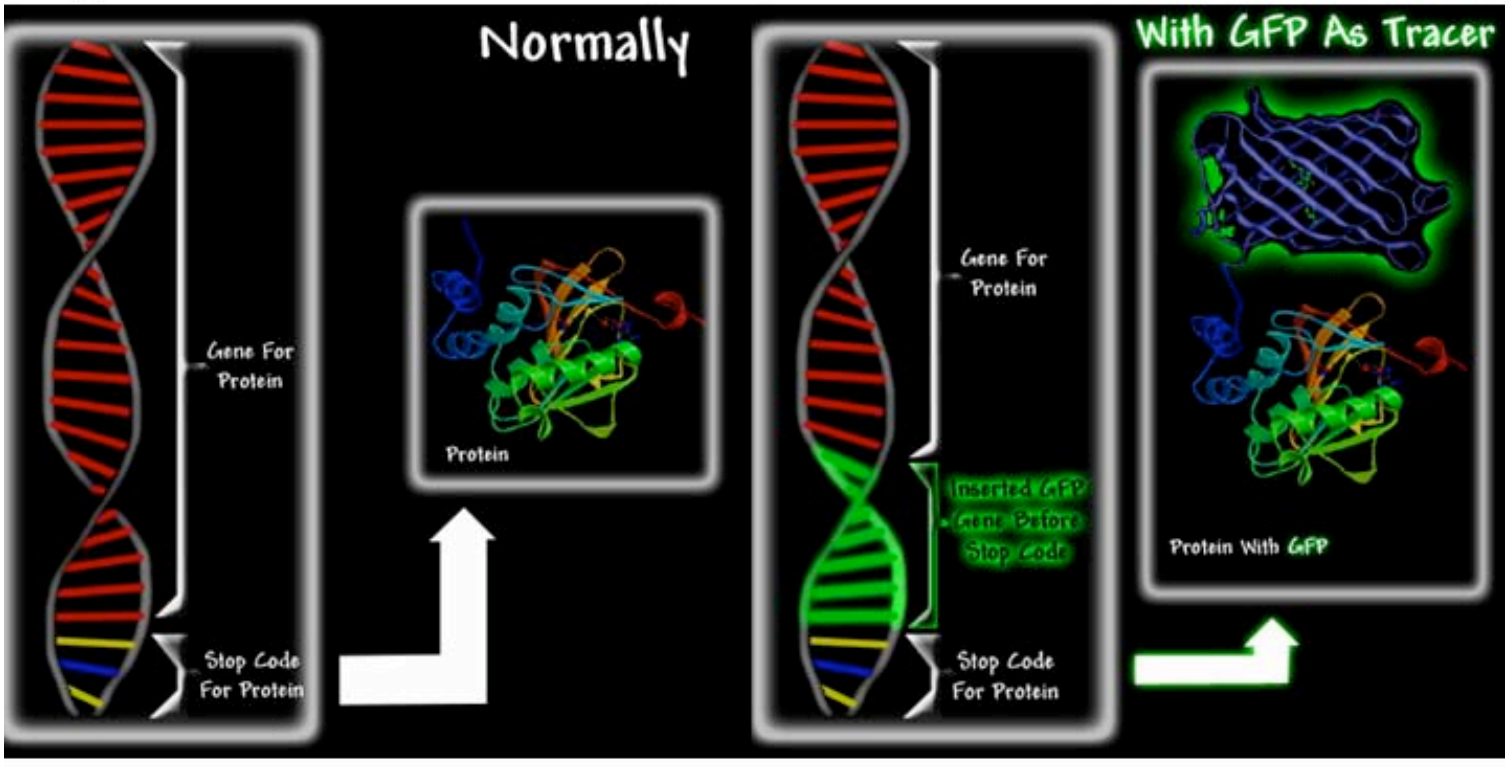

Fig. 6 Insertion of GFP gene into DNA. Douglas Prasher GFP School, (Science 263, 802-805, 1994). http://www.conncoll.edu/ccacad/zimmer/GFP-ww/ GFP-1.htm 
a specific promoter then it will be expressed in place of the protein, showing where and when the gene of interest is switched on (Douglas Prasher, from Zimmer, Marc website, Fig. 6).

Therefore, sGFP(S65T) can be effectively used to select the transformants expressing all the gene cassettes (El-Shemy et al.2004, 2006, 2007). The transgenic plants expressing $s G F P(S 65 T)$ grew and reproduced normally, and the GFP expression was inherited without any abnormalities. In conclusion, using $\operatorname{sGFP}($ S65T) as a reporter gene reduced or avoided the gene silencing in transgenic soybean .

\section{Materials and methods}

\section{Construction of chimeric genes}

Two plasmid vectors, pHVS and pHV, were constructed based on the pUC19 vector (Fig. $7 \mathrm{~A}$ and $\mathrm{B}$ ). pHV contains the hygromycin phosphotransferase coding region, hpt $(1.0 \mathrm{~kb})$, under regulatory control of the cauliflower mosaic virus (CaMV) 35S promoter, 35Spro, and the modified proglycinin (A1aB1b) cDNA, V3-1 (1.4kb), with a synthetic DNA encoding four continuous methionines. pHVS contains additionally a modified jellyfish green fluorescent protein coding region, $\operatorname{sGFP}(S 65 T)(0.8 \mathrm{~kb})$, under regulatory control of 35Spro in the flanking region of the V3-1 gene (El-Shemy et al,, 2004, 2006, 2007).

Initiation and proliferation of embryogenic cultures Transformation and regeneration systems for soybean were optimized according to methods described elsewhere
(Finer and Nagasawa, 1988; Hadi et al., 1996; Sato et al., 1993; El-Shemy et al., 2004, 2006, 2007). Soybean plants, cv. Jack, were grown in soil in a glass-house controlled at $25^{\circ} \mathrm{C}$ under natural light. Developing green pods were obtained when the immature cotyledons were about 4-5 mm long. After sterilization of the pod surface with $70 \%$ ethanol followed by 3 rinses with sterile water, the immature cotyledons were extracted, the end removed together with the embryonic axis, and the sample placed flat side up on MSD40 medium consisting of MS salts (Murashige and Skoog, 1962) and B5 vitamins (Gamborg et al., 1968) supplemented with 3\% sucrose, $40 \mathrm{mg} / \mathrm{l} 2,4-$ $\mathrm{D}$, and $0.2 \%$ Gelrite (Wako Pure Chemical Industries, Osaka, Japan) (pH7.0). Embryogenic tissues were initiated at $25^{\circ} \mathrm{C}$ under cool white fluorescent light (23/1 light regime, $5-10 \mu \mathrm{mol} / \mathrm{m}^{2} / \mathrm{s}$ ) for 3 to 4 weeks. Soybean embryogenic tissues were suspended and maintained in FN Lite liquid medium consisting of FN Lite macro salts, MS micro salts and B5 vitamins supplemented with $1 \mathrm{~g} / \mathrm{l}$ asparagine, $5 \mathrm{mg} / \mathrm{l} 2,4-\mathrm{D}$, and $1 \%$ sucrose $(\mathrm{pH}$ 5.8) (Finer and Nagasawa, 1988; El-Shemy et al.2004), and maintained by subculturing every week into $25 \mathrm{ml}$ of fresh FN Lite liquid medium in a $100 \mathrm{ml}$ flask (El-Shemy et al.2004, 2006).

\section{Transformation by particle bombardment}

Approximately $1 \mathrm{~g}$ of embryogenic suspension tissue was transferred to the center of MSD20 medium consisting of MS salts and B5 vitamins supplemented with $3 \%$ sucrose, $1 \mathrm{~g} / \mathrm{l}$ asparagine $20 \mathrm{mg} / \mathrm{l} 2,4-\mathrm{D}$, and $0.2 \%$ Gelrite (pH5.8) in a $9 \mathrm{~cm}$ petri dish. Bombardments were performed using a

A. pHVS

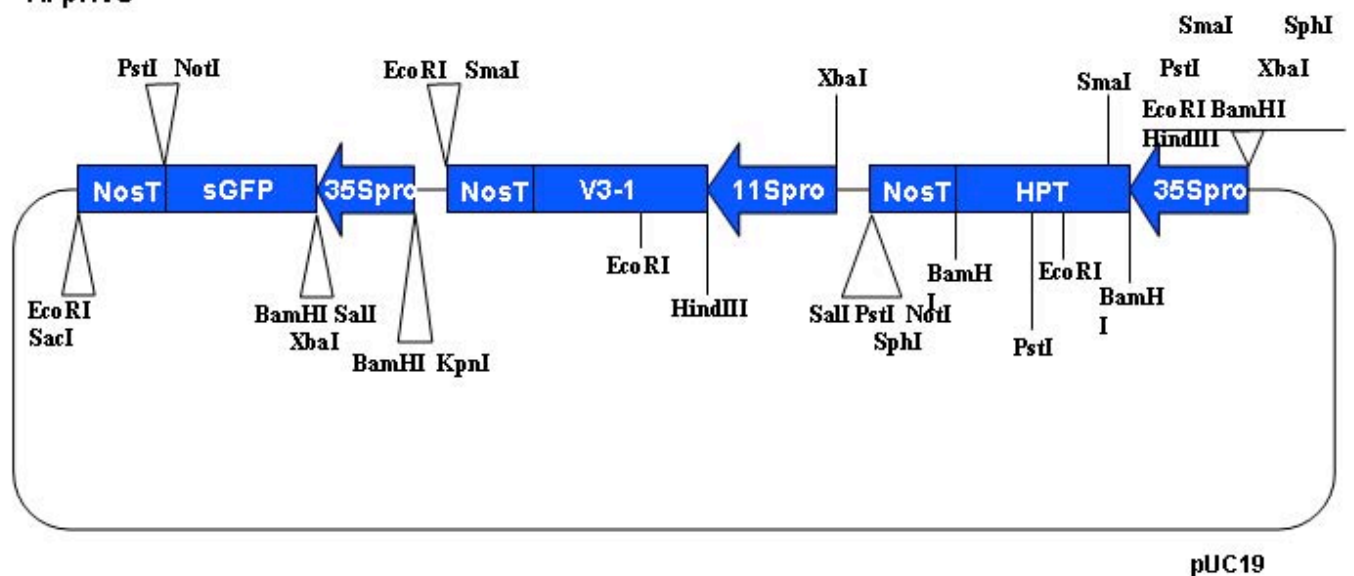

B. $\mathrm{pHV}$

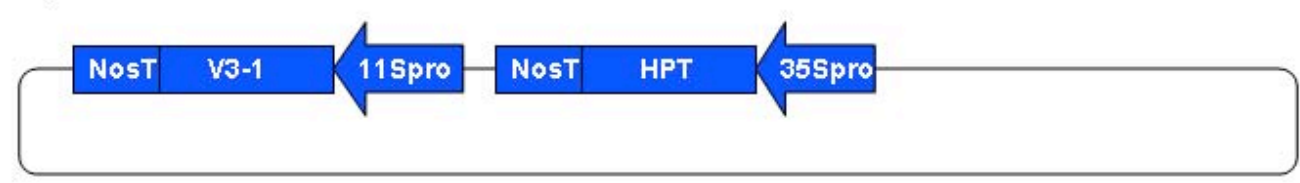

pUC19

Fig. 7. Structures of plasmid constructs for soybean transformation. A, pHVS contains a modified glycinin gene, V3-1, between hpt as a selectable gene and $s G F P(S 65 T)$ as a reporter gene. B, pHV contains V3-1 flanked by $h p t$ as a selectable gene. Restriction sites are indicated. 
Biolistic PDS-1000/He Particle Delivery System (Bio-Rad, Richmond, CA, USA) according to the instruction manual. Each sample of embryogenic tissue was bombarded twice with a pressure of $1350 \mathrm{psi}$.

Bombarded tissues were resuspended in the FN Lite medium. One week after bombardment the embryogenic tissues were transferred to fresh FN Lite medium containing $15 \mathrm{mg} / \mathrm{l}$ hygromycin B (Roche Diagnostics, Mannheim, Germany). The bombarded tissues were transferred to fresh antibiotic-containing FN Lite medium weekly for an additional 3 weeks. Then, white lumps of tissue that contained bright green lobes of embryogenic tissue were selected and transferred to fresh FN Lite medium containing $30 \mathrm{mg} / \mathrm{l}$ hygromycin $\mathrm{B}$. The hygromycin tolerant tissues were selected and resuspended in fresh antibiotic-containing FN Lite medium weekly for 3 additional weeks (El-Shemy et al., 2004, 2006).

Hygromycin tolerant embryos were subcultured in FNLOS3S3 liquid medium, which contained FN Lite macro salts, MS micro salts and B5 vitamins supplemented with $1 \mathrm{~g} / \mathrm{l}$ asparagine, $3 \%$ sucrose, and $3 \%$ sorbitol $(\mathrm{pH}$ 5.8). Three weeks after the suspension, excess liquid of the developing embryos was withdrawn with sterile filter paper, and the embryos were placed in dry petri dishes for 3 to 5 days. After the desiccation treatment, the embryos were placed on MSO medium containing MS salts, B5 vitamins, $3 \%$ sucrose, and $0.2 \%$ Gelrite (pH5.8). The germinating plantlets were transferred to $1 / 2$ B5 medium. After root and shoot elongation, plantlets were transferred to pots containing soil, and maintained under high humidity. Plantlets were gradually adapted to ambient humidity and placed in the glass-house.

\section{GFP detection}

The presence of sGFP(S65T) was detected by blue light excitation (Chiu et al., 1996). Embryos, cotyledons, leaves of regenerated plants and seeds were observed using a microscope (Leica Microsystems, Wetzlar, Germany) with a filter set providing $455-490 \mathrm{~nm}$ excitation and emission above $515 \mathrm{~nm}$.

\section{PCR and Southern blot analysis}

Total DNA was isolated from soybean leaves by the method of (Draper and Scott, 1988), and used to investigate the presence of the transgenes. PCR analysis was conducted to screen transformed plants in a $20 \mu$ l reaction mixture containing $10 \mathrm{ng}$ of genomic DNA, $200 \mu \mathrm{M}$ of each dNTP, $0.2 \mu \mathrm{m}$ of each primer, and 2.5 units of Ampli-taq Gold polymerase (Applied Biosystems, Foster City, CA USA) in the corresponding buffer. Reaction were hot-started $(9 \mathrm{~min}$ at $94^{\circ} \mathrm{C}$ ) and subjected to 30 cycles as follows: $30 \mathrm{sec}$ at $94^{\circ} \mathrm{C} ; 1 \mathrm{~min}$ at $55^{\circ} \mathrm{C}$; and $1 \mathrm{~min}$ at $72^{\circ} \mathrm{C}$. The last extension phase was prolonged to $7 \mathrm{~min}$ at $72^{\circ} \mathrm{C}$. The primer set for $h p t$ was designed for amplification of a $560 \mathrm{bp}$ fragment; sequences are 5'-ATCCTTCGCAAGACCCTTCCT-3' (35S promoter) and 5'-GGTGTCGTCCATCACAGTTTG-3' $(h p t)$. The primer set for $s G F P(S 65 T)$ was designed for amplification of a $708 \mathrm{bp}$ fragment; sequences are 5'- AAGGTACCGGATCCCCCCTCAGAA-3' and 5'AAGAGCTCCGATCTAGTAACATAGATGACACC-3'.

Southern blot analysis was conducted to confirm the stable integration of transgenes into soybean. Total DNA
$(10 \mu \mathrm{g})$ was digested with the restriction enzyme, Sacl, and digested DNA was separated by electrophoresis in a $1 \%$ agarose gel and transferred onto a hybond $\mathrm{N}+$ membrane (Amersham Biosciences, Buckinghamshire, England). Labeling and detection were conducted following the protocol of ECL direct nucleic acid labeling and detection (Amersham Biosciences). DNA fragments of the $\operatorname{sGP}(\mathrm{S} 65 T)$ gene and hpt gene were amplified from the plasmids with the same primer sets used for the PCR analysis, and served as hybridization probes on Southern blot membranes.

\section{Analysis of seed proteins in transgenic soybean} The subunit composition of seeds from individual transgenic soybean was analyzed by SDS-PAGE (Laemmli, 1970). A total globulin fraction was extracted from soybean seed meal by grinding with $50 \mathrm{mM}$ Tris- $\mathrm{HCl}$, $\mathrm{pH}$ 8.0. The supernatant was obtained after centrifugation at $15,000 \mathrm{~g}$ for $10 \mathrm{~min}$. The protein concentration was determined with a BCA protein assay (Pierce, Rockford, IL, USA) kit using bovine serum albumin as a standard. The protein solution was mixed with the same amount of a twice-concentrated SDS sample buffer containing 2 -mercaptoethnol. The proteins $(25 \mu \mathrm{g})$ from each sample were separated on a gels (Tricine-SDS-PAGE and SDSPAGE) containing $12 \%(\mathrm{w} / \mathrm{v})$ acrylamide and $0.2 \%(\mathrm{w} / \mathrm{v})$ bis-acrylamide, and were stained with Bio-Safe CBB G-250 stain (Bio-Rad).

\section{Acknowledgements}

Hany A. El-Shemy (Cairo University, Faculty of Agriculture, Biochemistry Department, Giza, Egypt) was supported by a postdoctoral fellowship from the Japanese Science and Technology Corporation. Mutasim M. Khalafalla (Commission for Biotechnology and Genetic Engineering, Sudan) was supported by a postdoctoral fellowship from the Japan Society for the Promotion of Science. The authors thank Yumi Nakamoto, Yumi Naganuma and Midori Yokoyama for technical assistance.

\section{References}

Carthew, R. W. (2001) Gene silencing by double-stranded RNA. Curr. Opin. Cell Biol. 13, 244-248.

Chalfie, M., Tu, Y., Euskirchen, G., Ward, W.W. \& Prasher, D.C. (2004) Green fluorescent protein as a marker for gene expression. Science, 263, 802-805.

Chiu, W-L., Niwa, Y., Zeng, W., Hirano, T., Kobayashi, H., and Sheen, J. (1996) Engineered GFP as a vital reporter in plants. Curr. Biol. 6, 325-330.

Dai, S., Zheng, P., Marmey, P., Zhang, S., Tian, W., Chen, S., Beachy, R.N., and Fauquet, C. (2001) Comparative analysis of transgenic rice plants obtained by Agrobacterium-mediated transformation and particle bombardment. Mol. Breed. 7, 25-33.

Draper, J., and Scott, R. (1988) The isolation of plant nucleic acids. In: Plant genetic transformation and gene expression, Draper, J., Scott, R., Armitage, P., Walden, R., eds. (London: Blackwell Scientific Publications), pp. 212-214.

Elliot, A., Campbell, J., Brettell, I., and Grof, P. (1998) Agrobacterium-mediated transformation of sugarcane 
using GFP as a screenable marker. Aust. J. Plant Physiol. 25, 739-743.

Elliot, A., Campbell, J., Dugdale, B., Brettell, R., and Grof, C. (1999) Green-fluorescent Protein facilitates rapid in vivo detection of genetically transformed plant cells. Plant Cell Rep. 18, 707-714.

El-Shemy, H.A., Khalafalla, M.M., Nishizawa, K., Utsumi, S., and Ishimoto, M. (2004) Isolation of soybean plants with stable transgene expression by visual selection based on green fluorescent protein. Mol. Breed. 14 227-238.

El-Shemy, H. A, Khalafalla, M.M., Fujita, K., and Ishimoto, M. (2006) Molecular control of gene co-suppression of transgenic soybean. J. Biochem. Mol. Biol. 39, 61-67.

El-Shemy, H. A, Khalafalla, M.M., Fujita, K., and Ishimoto, M. (2007) Improvement of protein quality in transgenic soybean plants. Biol. Plant. 51, 277-284.

Finer, J., and Nagasawa, A. (1988) Development of an embryogenic suspension culture of soybean [Glycine $\max ($ L.) Merrill]. Plant Cell Tiss. Org. Cult. 15, 125136.

Gamborg, O., Miller, R., and Ojima, K. (1968) Nutrient requirements of suspension cultures of soybean root cell. Exp. Cell Res. 50, 151-158.

Grant-Downton, R.T., and Dickinson, H.G. (2005) Epigenetics and its implications for plant biology. The epigenetic network in plants. Ann. Bot. 96, 1143-1164.

Hadi, M.Z., McMullen, M.D., and Finer J.J. (1996) Transformation of 12 different plasmids into soybean via particle bombardment. Plant Cell Rep. 15, 500-505.

Laemmli, U.K. (1970) Cleavage of structural proteins during the assembly of the head bacteriophage T4. Nature 277, 680-685.

Lessard, P.A., Kulaveerasingam, H., York, G.M., Strong, A., and Sinskey, A.J. (2002) Manipulating gene expression for the metabolic engineering of plants. Metab. Eng. 4, 67-79.

Luff, B., Pawlowski, L., and Bende, J. (1999) An inverted repeat triggers cytosine methylation of identical sequences in Arabidopsis. Mol. Cell. 3, 505-511.

Matzke, A., and Matzke, M. (1995) Trans-inactivation of homologous sequences in Nicotiana tabacum. In: Gene silencing in higher plants and related phenomena in other eukaryotes, Meyer, P. ed. (Berlin: Springer), pp1-14.

Matzke, M., Matzke, A.J.M., and Kooter, J.M. (2001) RNA: guiding gene silencing. Science 293, 1080-1083.

Meyer, P. (1995) Understanding and controlling transgene expression. Trends Biotechnol. 13, 332-337.
Meyer, P. (2000) Transcriptional transgene silencing and chromatin components. Plant Mol. Biol. 43, 221-234.

Murashige, T., and Skoog, F. (1962) A revised medium for rapid growth and bioassays with tobacco tissue culture. Physiol. Plant 15, 473-497.

Napoli, C.,Lemieux, C., and Jorgensen, R.A. (1990) Introduction of a chimeric chalcone synthase gene in petunia results in reversible cosuppression of homologous genes in trans. Plant Cell 2, 279-289.

Richards, H.A., Halfhill, M.D., Millwood, R.J., and Stewart, C.N. (2003) Quantitative GFP fluorescence as an indicator of recombinant protein synthesis in transgenic plants. Plant Cell Rep. 22, 117-121.

Sato, S., Newell, C., Kolacz, K., Tredo, L., Finer, J., and Hinchee, M. (1993) Stable transformation via particle bombardment in two different soybean regeneration systems. Plant Cell Rep. 12, 408-413.

Spiker, S., and Thompson,W. F. (1996) Nuclear matrix attachment regions and transgene expression in plants. Plant Physiol. 110, 15-21.

Stam, M, Mol, J., and Kooter, J. (1997) The silence of genes in transgenic plants. Ann. Bot. 79, 3-12.

Stewart, J.C.N. (2001) The utility of green fluorescent protein in transgenic plants. Plant Cell Rep. 20, 376382.

Taylor, N.G., and Fauquet, C.M. (2002) Microparticle bombardment as a tool in plant science and agricultural biotechnology. DNA Cell Biol. 21, 963-977.

Van der Krol, A., Lenting, P., Veenstra, J,. van der Meer, I., Gerats, A., Mol, J., and Stuitje, A. 1988. An anti-sense chalcone synthase gene in transgenic plants inhibits flower pigmentation. Nature 333, 866-869

Vance, V., and Vaucheret, H. (2001) RNA silencing in plants - defense and counter defense. Science 292, 2277-2280.

Vaucheret, H., Beclin, C., Elmayan, T., Feuerbach, F., Godon, C., Morel, J-B., Mourrain, P., Palauqui, J.-C., and Vernhettes, S. (1998) Transgene-induced gene silencing in plants. Plant J. 16, 651-659.

Wang, M-B., and Waterhouse, P. (2002) Application of gene silencing in plants. Curr. Opin. Plant Biol. 5, 146150.

Waterhouse, P.M.,Wang,M., and Finnegan, E.J. (2001a) Role of short RNAs in gene silencing. Trends Plant Sci. 6, 297-301.

Waterhouse,P. M., Wang,M. B., and Lough,T. (2001b) Gene silencing as an adaptive defence against viruses. Nature 411, 834-842.

Zimmer, M. (2007) Green Fluorescent Protein. http:// www.conncoll.edu/ccacad/zimmer/GFP-ww/GFP-1. htm (accessed 4 December 2007). 


\section{Further Reading}

Caister Academic Press is a leading academic publisher of advanced texts in microbiology, molecular biology and medical research. Full details of all our publications at caister.com

- MALDI-TOF Mass Spectrometry in Microbiology Edited by: M Kostrzewa, S Schubert (2016) www.caister.com/malditof

- Aspergillus and Penicillium in the Post-genomic Era Edited by: RP Vries, IB Gelber, MR Andersen (2016) www.caister.com/aspergillus2

- The Bacteriocins: Current Knowledge and Future Prospects Edited by: RL Dorit, SM Roy, MA Riley (2016)

www.caister.com/bacteriocins

- Omics in Plant Disease Resistance Edited by: V Bhadauria (2016) www.caister.com/opd

- Acidophiles: Life in Extremely Acidic Environments Edited by: R Quatrini, DB Johnson (2016) www.caister.com/acidophiles

- Climate Change and Microbial Ecology: Current Research and Future Trend

Edited by: J Marxsen (2016)

www.caister.com/climate

- Biofilms in Bioremediation: Current Research and Emerging Technologies

Edited by: G Lear (2016)

www.caister.com/biorem

- Microalgae: Current Research and Applications Edited by: MN Tsaloglou (2016) www.caister.com/microalgae

- Gas Plasma Sterilization in Microbiology: Theory, Applications, Pitfalls and New Perspectives Edited by: H Shintani, A Sakudo (2016) www.caister.com/gasplasma

- Virus Evolution: Current Research and Future Directions Edited by: SC Weaver, M Denison, M Roossinck, et al. (2016) www.caister.com/virusevol

- Arboviruses: Molecular Biology, Evolution and Control Edited by: N Vasilakis, DJ Gubler (2016) www.caister.com/arbo

- Shigella: Molecular and Cellular Biology Edited by: WD Picking, WL Picking (2016) www.caister.com/shigella

-Aquatic Biofilms: Ecology, Water Quality and Wastewater Treatment

Edited by: AM Romaní, H Guasch, MD Balaguer (2016)

www.caister.com/aquaticbiofilms

- Alphaviruses: Current Biology

Edited by: S Mahalingam, L Herrero, B Herring (2016)

www.caister.com/alpha

- Thermophilic Microorganisms

Edited by: F Li (2015)

www.caister.com/thermophile
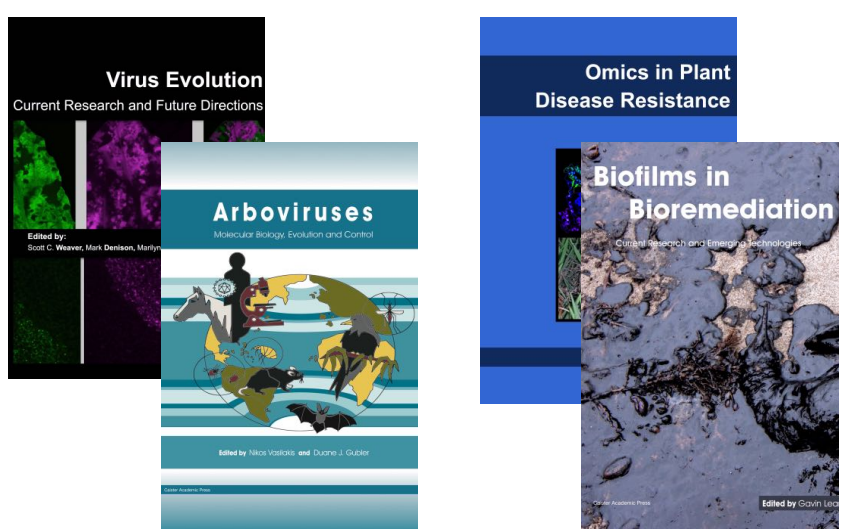
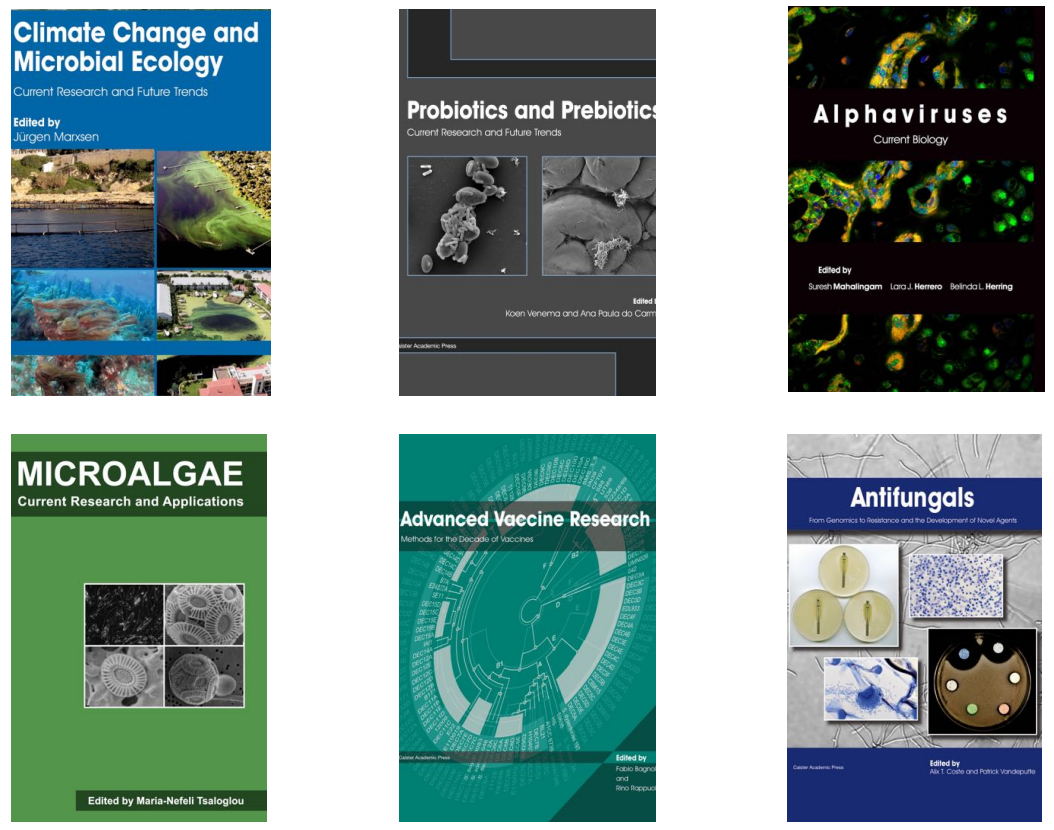

- Flow Cytometry in Microbiology: Technology and Applications Edited by: MG Wilkinson (2015) www.caister.com/flow

- Probiotics and Prebiotics: Current Research and Future Trends Edited by: K Venema, AP Carmo (2015) www.caister.com/probiotics

- Epigenetics: Current Research and Emerging Trends Edited by: BP Chadwick (2015) www.caister.com/epigenetics2015

- Corynebacterium glutamicum: From Systems Biology to Biotechnological Applications

Edited by: A Burkovski (2015)

www.caister.com/cory2

- Advanced Vaccine Research Methods for the Decade of Vaccines

Edited by: F Bagnoli, R Rappuoli (2015)

www.caister.com/vaccines

- Antifungals: From Genomics to Resistance and the Development of Novel Agents

Edited by: AT Coste, P Vandeputte (2015)

www.caister.com/antifungals

- Bacteria-Plant Interactions: Advanced Research and Future Trends Edited by: J Murillo, BA Vinatzer, RW Jackson, et al. (2015) www.caister.com/bacteria-plant

\section{- Aeromonas}

Edited by: J Graf (2015)

www.caister.com/aeromonas

- Antibiotics: Current Innovations and Future Trends

Edited by: S Sánchez, AL Demain (2015)

www.caister.com/antibiotics

- Leishmania: Current Biology and Contro Edited by: S Adak, R Datta (2015) www.caister.com/leish2

- Acanthamoeba: Biology and Pathogenesis (2nd edition) Author: NA Khan (2015)

www.caister.com/acanthamoeba2

- Microarrays: Current Technology, Innovations and Applications Edited by: Z He (2014)

www.caister.com/microarrays2

- Metagenomics of the Microbial Nitrogen Cycle: Theory, Methods and Applications

Edited by: D Marco (2014)

www.caister.com/n2 